\title{
Environmentally induced short-term variability in the growth rates of larval herring
}

\author{
A. Gallego ${ }^{1, *}$, M. R. Heath ${ }^{1}$, E. McKenzie ${ }^{2}$, L. H. Cargill ${ }^{1}$ \\ 'SOAEFD Marine Laboratory, PO Box 101, Victoria Road, Aberdeen AB11 9DB, Scotland, UK \\ ${ }^{2}$ Department of Statistics and Modelling Science, University of Strathclyde, 26 Richmond Street, Glasgow G1 1 XH, Scotland, UK
}

\begin{abstract}
The growth of herrng Clupea harengus larvae within a patch tracked for approximately $20 \mathrm{~d}$ in the Orkney-Shetland area (north of Scotland) was investigated using otolith microstructure and, in a supporting role, condition factor analyses. Daily otolith growth responded conservatively to external factors, there being significant autocorrelation within individual otolith increment sequences. Past growth history explained most of the variation of the data. Both otolith microstructure and condition factor analyses yielded consistent results, indicating that short term variations in growth rate were related to environmental factors such as wind-induced turbulence level, and changes in illumination and prey concentration. A dome-shaped effect of wind-generated turbulence on larval growth was detected, which indicated a maximum response at a wind speed of approximately $14.5 \mathrm{~m} \mathrm{~s}^{-1}$, a value very close to the speeds predicted by theoretical studies to generate maximum ingestion rates of larval fish.
\end{abstract}

KEY WORDS: Fish larvae - Growth Environment Turbulence Otolith

\section{INTRODUCTION}

The survival of fish larvae under natural circumstances is largely dependent on stage-specific mortality rate, i.e. the interaction between growth and mortality (Houde 1994). These 2 processes are interrelated since survival over any development interval is the product of mortality rate $\left(\mathrm{d}^{-1}\right)$ and stage duration (d). Mortality rate generally decreases with increasing body size due to a variety of size-related effects on predator-prey interactions (Fuiman 1994), and hence the cumulative mortality for a population of fast growing individuals is less than that for slow growing individuals subject to the same predation rate (Houde \& Schekter 1980, Houde 1987, 1994).

Early attempts to detect growth variability in fish larvae and relate it to environmental features were, with a few exceptions, unsuccessful (Heath 1992). Investigators examined the mean growth of the population, usually averaged over time periods of days or weeks, in relation to large-scale spatial (10 to $100 \mathrm{~km}$ ) differ-

\footnotetext{
•E-mail: a.gallego@marlab.ac.uk
}

ences in prey abundance or environmental characteristics. However, this large-scale variation in time and space may account for only a small part of the total variability in growth. Small-scale spatial and temporal variability, which could be more important for larval survival, is not examined in this approach. For example, small-scale turbulence may vary on time scales of minutes to hours and over short distances, particularly in the vertical plane. It is now evident that small-scale turbulence may have a profound influence on the encounter rate and capture success of planktonic predators (Mackenzie et al. 1994). Thus there is scope for considerable within-population variability in growth induced by ingestion rate variability, over and above additional sources of variation between individuals due to foraging experience, genetic differences, etc. Studies of the effect of individual variability in growth on larval survival have shown that this factor may be as, or more, important than the mean population growth rate (Pepin 1988/1989, Rice et al. 1993).

A different strategy is required to investigate the influence of the environment on individual larval growth rates. It is necessary to monitor variability over time at individual, as well as population, level and 
relate growth to the time sequence of environmental parameters encountered by the population. Largescale spatial surveys are inappropriate for this task. An alternative approach is time-series sampling of a patch of larvae and monitoring the evolution of individual growth histories within the population concurrently with the environmental conditions. Otolith microstructure analysis is particularly valuable for such studies because otolith daily increments reflect the growth histories of individuals through time up to the moment of capture. In this paper we describe an analysis of data collected from such an exercise carried out in September 1986, which allows us to partition growth rate variability between environmental and internal sources. A detailed knowledge of these processes is essential to forecast the effect of physical and biological change (natural or man-made) in the marine environment on the development and survival of fish populations.

\section{MATERIALS AND METHODS}

A patch of horring Clupea harengus larvae was located off the west coast of the Orkney Isles in September 1986 . The centre of the patch (approximately $59^{\circ} 00^{\prime} \mathrm{N}, 04^{\circ} 00^{\prime} \mathrm{W}$ ) was marked with drifting buoys. The buoys were tracked between 5 and 25 September, and sampling was carried out nearby during 5 to 14 and 23 to 24 September. Full details of the patch tracking and sampling protocols have been reported by Heath \& Rankine (1988), Heath et al. (1988) and Heath (1989), and will be only briefly summarised below. For a description of the hydrography of the study area (Fig. 1) see Heath et al. (1987).

Drift tracking. The drifting buoys used during the initial part of the survey ( 7 to 14 September) consisted of a surface marker attached to a drogue $(1 \mathrm{~m}$ diameter, $10 \mathrm{~m}$ length) situated at a depth of approximately $30 \mathrm{~m}$. Their position was estimated approximately every hour by directing the ship towards the surface marker and logging the position of the vessel. These buoys were deployed on 7 and 11 September, respectively. An 'Argos' satellite-tracked drifting buoy with a $15 \mathrm{~m}$ long drogue situated at a depth of $30 \mathrm{~m}$ was deployed on 13 September.

As with most drift tracking studies, the drogued buoys did not follow precisely the trajectory of the centre of the patch of larvae. For this reason, the distribution of larvae was re-surveyed at approximately $3 \mathrm{~d}$ intervals and the buoys re-deployed. The error introduced by the divergence of buoy and patch trajectories was considered to be small and there is a good basis to conclude that the same group of larvae was tracked throughout the study period (Heath \& Rankine 1988). The discrepancy between buoy tracks and patch tra-

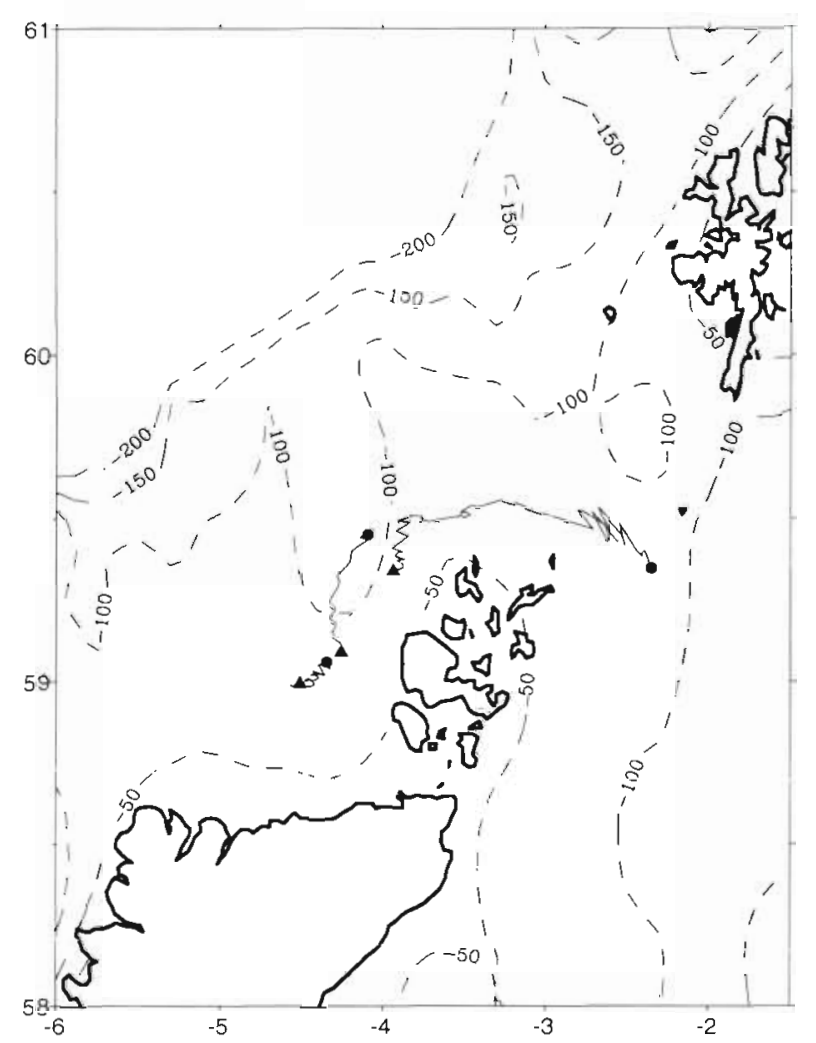

Fig. 1. The study area, with depth contours $\leq 200 \mathrm{~m}$ and corrected trajectory (see text) of the drifting buoys. The overall direction of the displacement was northeast. Start ( $\mathbf{\Delta}$ ) and end (-) positions are marked

jectory was found to be accounted for by a vector representing $0.8 \%$ of wind velocity (Heath \& Rankine 1988). In subsequent analyses of drift buoy tracks, data corrected for wind displacement have been used.

Biological sampling. Discrete depth samples of herring larvae and other planktonic organisms were taken at 3 to $4 \mathrm{~h}$ intervals adjacent to the drifting buoy with an opening and closing multiple net (mesh size $250 \mu \mathrm{m}$ ) version of the Gulf III (Dunn et al. 1985) which sampled 4 contiguous depth layers in a single oblique tow from ca $5 \mathrm{~m}$ above the sea bed to the surface. Further data on herring larvae vertical distributions were collected from water samples taken with a $150 \mathrm{~mm}$ diameter hose and pump system with its inlet positioned at discrete depths. The flow rate of the pump was $250 \mathrm{~m}^{3} \mathrm{~h}^{-1}$ and the outflow was filtered through. 200 um mesh. Similar systems have been described in studies of the vertical distribution of herring larvae (e.g. Munk et al. 1989). Herring larvae were immediately identified in the sample and preserved separately from the rest of the plankton. Ichthyo- and zooplankton samples were preserved in $4 \%$ neutral buffered formaldehyde.

A $1 \mathrm{~m}$ diameter drum net (250 $\mathrm{mm}$ mesh size) was deployed in a double oblique tow at approximately mid- 
night each day to collect larvae for otolith, gut content and length-weight analyses. The catch was immediately fixed by a brief exposure to $4 \%$ formaldehyde. Two sets of larvae were selected at random from the catch for otolith and length-weight analysis. Larvae for otolith analysis were preserved in $90 \%$ neutral ethanol whilst those for condition factor analysis were measured (total and standard length, SL), freeze dried on teflon discs and stored individually in glass tubes. The rest of the catch was preserved in $4 \%$ neutral buffered formaldehyde.

Discrete micro- and mesozooplankton samples were collected at various depths with $50 \mathrm{l}$ water bottles. These samples were filtered through $40 \mu \mathrm{m}$ mesh and preserved in $4 \%$ neutral buffered formaldehyde.

Environmental measurements. Hydrographic sampling: Temperature and salinity measurements were taken at each plankton sampling station using standard reversing water bottle casts and a conductivitytemperature-depth (CTD) probe. Surface (depth $4 \mathrm{~m}$ ) temperature and salinity were recorded aboard the vessel at 10 min intervals by a thermosalinograph connected to the vessel's pumped seawater supply.

Meteorological measurements: True wind speed and direction were calculated from measurements of apparent wind speed and direction recorded every $2 \mathrm{~h}$ by a masthead anemometer, and the ship's speed and direction.

Light intensity at the sea surface was measured by a masthead mounted level-response photodiode fitted with a cosine collector (see Heath et al. 1988). Mean surface light intensities for each hour were calculated from 5 min averages of measurements taken at $3 \mathrm{~s}$ intervals.

Laboratory analyses. On return to the laboratory, every zooplankton organism in the catch was identified to the lowest taxonomic level, down to developmental stage if possible. Herring larvae in the samples were counted and all, or the majority, of them were measured (SL) to the nearest $0.1 \mathrm{~mm}$. The guts of selected herring larvae were dissected, and prey items were identified to the lowest taxonomic level and measured under the microscope. 276 larvae were used in this analysis. A total of 1105 freeze-dried larvae were weighed to the nearest $\mu \mathrm{g}$.

Herring larvae preserved for otolith analysis were measured (SL, uncorrected for shrinkage), and the sagittae were extracted from a total of 117 individuals. Increment rings were counted from a VDU screen connected to a compound microscope with a resulting onscreen magnification of $3500 \times$. The left and right sagittae were each counted twice and from those 2 counts an average for each sagitta was calculated. In the event of a discrepancy $\geq 3$ rings between these 2 averagyes, the areraye of the sayitid wiin the $z$ most similar counts was used. The width of each increment ring was measured along the longest otolith axis using an
Image Analysis System (Applied Imaging, Sunderland, England), following routines described by Rankine \& Cargill (1991). The resolution of these increment width measurements was approximately $0.2 \mu \mathrm{m}$.

Data analysis. Physical and biological factors: Daily averages of light intensity at the sea surface, surface seawater temperature within a $5 \mathrm{~km}$ radius of the drifting buoy and wind speed were calculated from the environmental data collected aboard the research vessel. Sea surface water temperatures for dates when the vessel was not in the proximity of the buoy were linearly interpolated from valid data. Wind mixing is a factor that contributes to turbulence in the water column. As most herring larvae remained within the mixed layer (Heath et al. 1988), the minimum (i.e at the bottom of the mixed layer) daily wind-induced turbulence to which the larvae were exposed was calculated from daily averages of wind speed at the surface from the empirical relationship proposed by MacKenzie \& Leggett (1991) and the daily average depth of the mixed layer along the track of the larval patch:

$$
\log \varepsilon_{w}=-5.104 Z^{0.079}+0.748 \log \left(W^{3}\right)+0.945
$$

where $\varepsilon_{w w}\left(\mathrm{~W} \mathrm{~m}^{-3}\right)$ is turbulent kinetic energy dissipation rate due to wind stress, $Z$ is mixed layer depth $(\mathrm{m})$ and $W$ is wind speed $\left(\mathrm{m} \mathrm{s}^{-1}\right)$. Buoy displacement speed, as calculated from successive latitude and longitude coordinates, indicated the velocity of the current transporting the larval patch. Tide-generated turbulent energy dissipation rate is proportional to the parameter $u^{3} / h$, where $u$ is $M_{2}$ depth averaged tidal velocity and $h$ is water column height (Bowers \& Simpson 1987). Tide-induced turbulence was estimated as

$$
\varepsilon_{t}=0.006\left(\frac{u^{3}}{h}\right) \times 10^{3}
$$

where $\varepsilon_{t}\left(\mathrm{~W} \mathrm{~m}^{-3}\right)$ is turbulent kinetic energy dissipation rate due to tidal shear, $u\left(\mathrm{~m} \mathrm{~s}^{-1}\right)$ is tidal speed and $h(\mathrm{~m})$ is water column height (MacKenzie \& Leggett 1991). We used buoy displacement speed as an approximation of $u$.

The amount of zooplankton is only a partial indicator of the quantity of food available to the herring. Other factors are the co-occurrence of larvae and prey in the same layers of the water column and the suitability of those plankters as prey for the larvae in terms of size, palatability and catchability. The amount of food available to each of six $2 \mathrm{~mm}$ length classes of larvae between $<8 \mathrm{~mm}$ and $\geq 16 \mathrm{~mm}$ ( $\mathrm{SL}$, uncorrected for shrinkage) was estimated from the abundance of prey size classes and species present which also occurred in stomachs of larvae. Estimates of food available for each length class were subsequently weighted by the proportion of the larval population in the depth layer where each zooplankton sample was taken, as calcu- 
lated from an empirical model of the vertical distribution of larvae developed from the same study (Heath et al. 1988). Daily mean abundances (ind. $\mathrm{m}^{-3}$ ) of available prey items were converted to biomass (mg dry weight $\mathrm{m}^{-3}$ ) using standard weights for each species and developmental stage available in a database at SOAEFD Marine Laboratory (Hay et al. 1991). These values will be referred to as prey availability, without considering possible effects of encounter rate on actual availability of prey items to the larvae.

Statistical analysis: Increment deposition on otoliths of herring larvae sampled during the study was assumed to have daily periodicity. Daily deposition, from the time of first-feeding, has been demonstrated for the species (Gjosæter \& Oiestad 1981, Lough et al. 1982, Messieh et al. 1987, Moksness \& Wespestad 1989, Campana \& Moksness 1991). The microstructure of the otoliths was analysed to quantify effects of several factors on daily growth of the larvae. Only those increments deposited during the period of the survey (6 to 24 September 1986) were considered. Furthermore, all data from otoliths where measurement errors were suspected in one or more increments were discarded prior to the statistical analysis. These were abnormally wide increments (several times the average ring width), generally close to the nucleus (see 'Results'). Multiple regression analyses were used to investigate the potential relationships between otolith daily increment widths and larval condition factor, and other variables measured throughout the survey period. The selection of independent variables for the model was mainly governed by biological criteria, although the availability of a suitable time series throughout the investigation was also taken into consideration (see discussions about food and temperature variables in 'Results' and 'Discussion'). The first type of otolith microstructure models tested could be generally described as

$$
\text { WIDTH }_{t l}=\mu_{t t}+\varepsilon_{t}
$$

where WIDTH Wit $_{\text {it }}$ the width of an individual otolith daily increment $i$ on Day $t, \mu_{i t}$ is the multiple regression component of the model and $\varepsilon_{l i}$ is random noise.

The effect of intra-fish variation additional to that derived from past individual growth history was tested by a model with an additional term, $\alpha$, a random variable $\left[\alpha \approx N\left(0, V_{\alpha}\right)\right]$ representing intrafish variation with a particular value for each individual otolith. Thus, for the incremental width of the ith otolith on Day $t$, we would have

$$
\text { WIDTH }_{1 t}=\mu_{1 t}+\alpha_{1}+\varepsilon_{1 t}
$$

Therefore, $\ln W I D T H_{1 t} \approx N\left(\mu_{t}, V+V_{u}\right)$, and the variance components, $V$ and $V_{\alpha}$, could be estimated simultaneously with the regression function $\mu_{i t}$ from the residuals.

Unlike the otolith data, the condition factor data do not contain any individual fish history information. Each measurement is essentially a smoothed integral of development over a number of days prior to capture. Thus these data are not simply instantaneous measures of current feeding status and are rather difficult to interpret. Their analysis here is presented in a supporting role for the otolith data.

\section{RESULTS}

\section{Physical measurements}

\section{Surface light intensity}

Time series of daily mean and maximum surface irradiance during the survey period are given in Fig. 2. For a time series of hourly means see Fig. 5a in Heath (1989). Relatively bright, cloud free weather prevailed on 7,11 and 17 September, while overcast conditions predominated on 9, 12 to 14 and 19 to 22 September.

\section{Turbulence in the water column}

Daily averages, minima and maxima of measurements of wind speed taken every $2 \mathrm{~h}$ are shown in Fig. 3a. Strong winds occurred throughout most of the survey period, with daily average wind speeds exceeding $10 \mathrm{~m} \mathrm{~s}^{-1}$ from 6 to 21 September, except on 12 and 16 September. Wind speeds decreased below this level

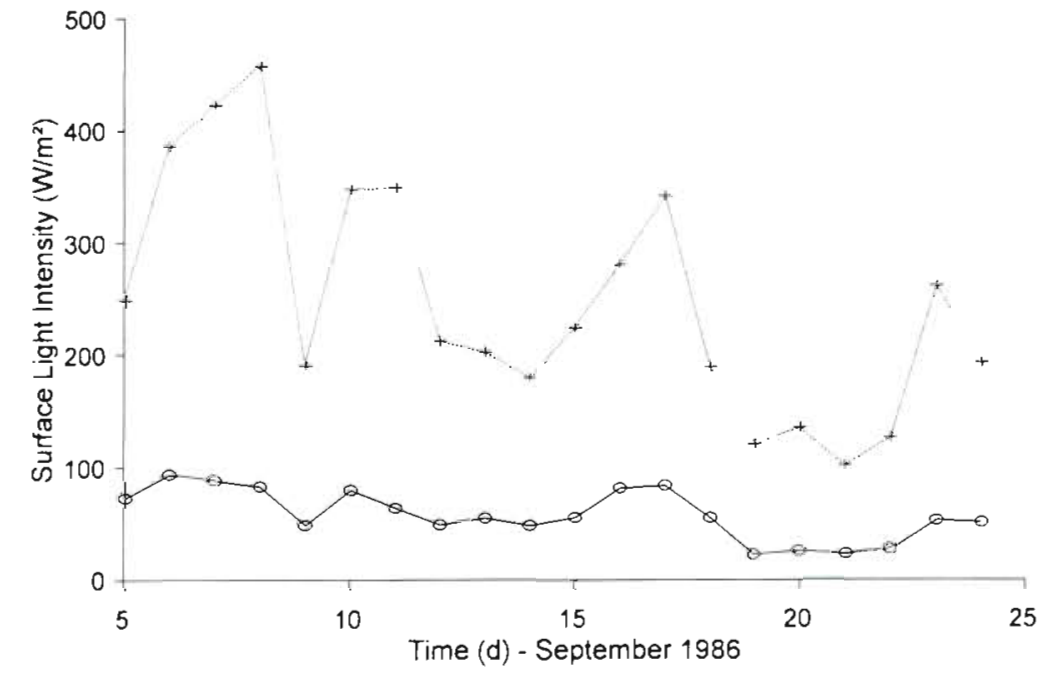

Fig. 2. Daily mean (-o) and maxımum $(\cdots+\cdots)$ surface light intensıly $\left(\mathrm{W} \mathrm{m}^{-2}\right)$ 
towards the end of the survey, from 22 September. The minimum (i.e. at the bottom of the mixed layer) wind-generated turbulent kinetic energy dissipation rate which the larvae were exposed to was highest on 7, 9, 15 and especially 20 September (Fig. 3b).

Trajectories (Fig 1) of the drifting buoys were used to calculate daily average patch drift velocity (Fig. 4a). Tidegenerated $\varepsilon_{\mathrm{t}}$ values (Fig. $4 \mathrm{~b}$ ) revealed 2 peaks $\left(0.32\right.$ and $\left.1.50 \mathrm{~W} \mathrm{~m}^{-3}\right)$ centred on 16 and 20 September, respectively. Data of $\varepsilon$ were $\log$-transformed in the figures to include these maxima. The increase in displacement velocity between 19 and 23 September coincided with the transport of the patch by the current through the Fair Isle Channel.

\section{Stratification and sea water temperature}

Temperature profiles indicated the thickness of the mixed layer. Differences in temperature between the surface and the bottom were small (maximum differences $<2^{\circ} \mathrm{C}$ ). Larvae were transported along the front separating isothermal and stratified water (Heath \& Rankine 1988). The water column along their trajectory was well mixed during 5 to 9 and 15 to 24 September. From 9 to 14 September the water column was stratified, with the mixed layer approximately delimited by the $11.2^{\circ} \mathrm{C}$ isotherm. As the larvae remained mostly within the mixed layer (Heath et al. 1988), surface temperature along the trajectory of the patch was considered to represent the temperature experienced by the larvae throughout the survey (Fig. 5). Water temperature declined by $<1^{\circ} \mathrm{C}$ during that period.

\section{Biological analysis}

Availability of prey to the larvae

The length range of prey eaten by larvae in each length class is given in Table 1. Comparison of the prey in stomachs of larvae with zooplankton in the water column showed that larvae rejected all stages, other

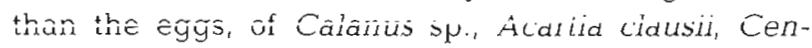
tropages hamatus and Metridia lucens. Also rejected were the copepodite stages of Paracalanus parvus, and the older (copepodite $\mathrm{V}$ and VI) stages of Temora longicornis. Eggs of copepods and other invertebrates were abundant in the stomachs of the larvae relative to their presence among the plankton.

Table 1 Size range of prey in the stomachs of larvae of the length classes in the analysis

\begin{tabular}{|lcc|}
\hline $\begin{array}{l}\text { Length class } \\
(\mathrm{mm})\end{array}$ & $\begin{array}{c}\text { Smallest prey } \\
(\mathrm{mm})\end{array}$ & $\begin{array}{c}\text { Largest prey } \\
(\mathrm{mm})\end{array}$ \\
\hline$<8$ & 0.07 & 0.42 \\
$8-10$ & 0.08 & 0.60 \\
$10-12$ & 0.10 & 0.77 \\
$12-14$ & 0.11 & 0.80 \\
$14-16$ & 0.12 & 0.83 \\
$\geq 16$ & 0.14 & 0.93 \\
\hline
\end{tabular}



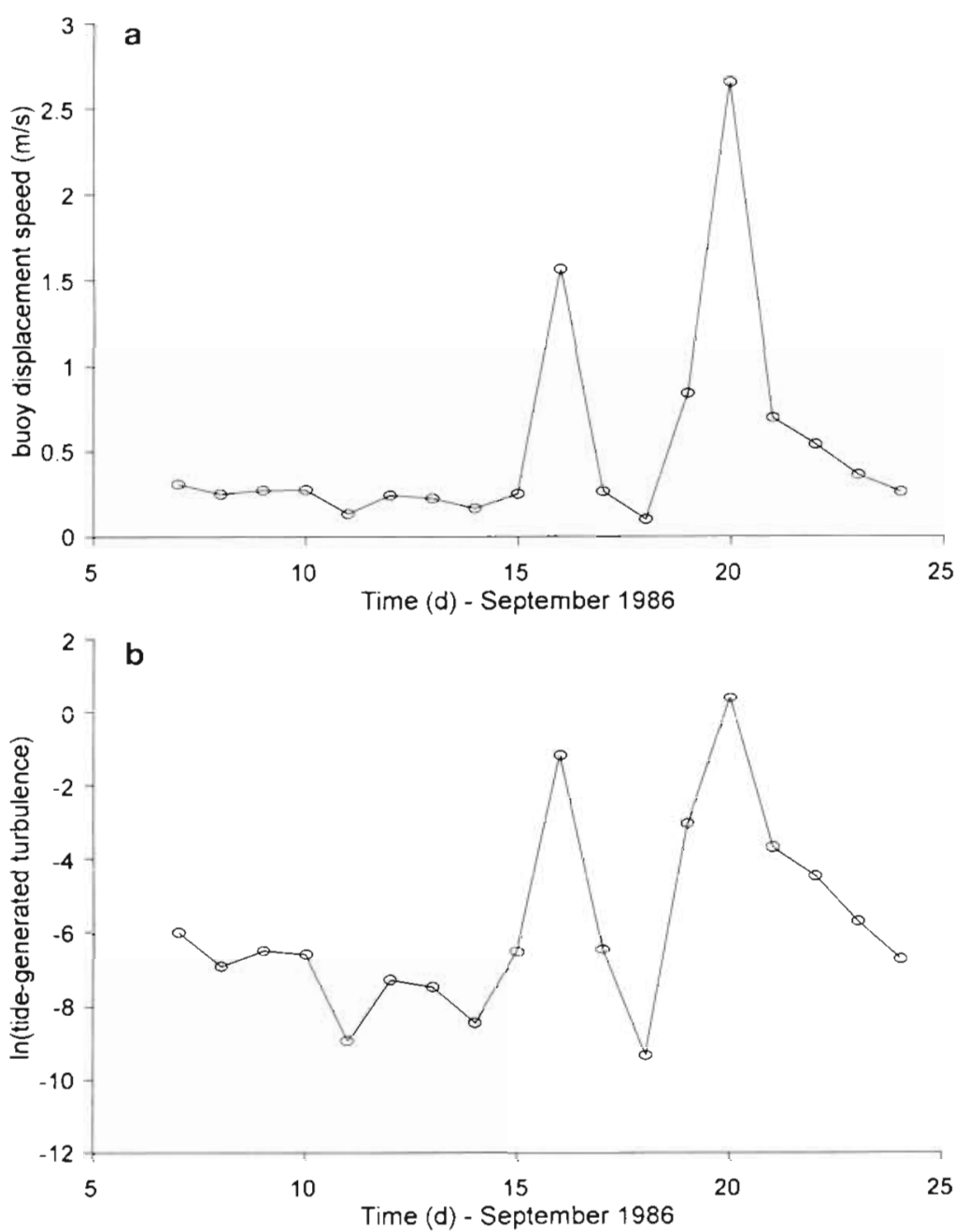

Fig. 4. (a) Daily mean buoy displacement speed $\left(\mathrm{m} \mathrm{s}^{-1}\right)$, and (b) daily mean tide-generated turbulence $\left(\mathrm{W} \mathrm{m}^{-3}\right)$, natural-log transformed
Microstructure of larval otoliths

The total number of increment rings per otolith ranged from 1 to 33 , although the majority had $<7$ rings (mean $=9$ rings, mode $=4$ rings). Assuming that these increments were deposited daily from the onset of exogenous feeding ( $<8$ to $10 \mathrm{~d}$ ), it can be concluded that most sampled larvae were less than 2 wk old. There was a strong relationship $\left(\mathrm{r}^{2}=0.68, \mathrm{p}<0.001, \mathrm{n}=\right.$ 117 ) between fish standard length (SL) and otolith growth radius $(R$, the sum of the width of all daily increment rings, excluding the nucleus):

$$
\ln \mathrm{SL}=2.047+0.243 \ln R
$$

Regression of log-log transformed, rather than linear, data explained a greater proportion of the variance and eliminated any trend in the residuals.

Narrow individual increments $(<0.2 \mu \mathrm{m}$, the resolution limit of the system) might not be discriminated and could be grouped together. Rings several times wider than the average close to the nucleus and/or abnormally wide first increment(s) compared to later ones are likely indications of this bias. As a result, 19 of the 117 otoliths were identified as suspect and discarded prior to the statistical analysis. The relationship between larval 'age' (ring number) and length at capture was

$$
\ln \mathrm{SL}=2.121+0.215 \ln A G E
$$

The time series of prey biomass available to each larval length class throughout the survey is given in Fig. 6. As no zooplankton data were collected during the period 15 to 22 September, while the vessel was engaged in other survey work, prey availability valties for the missing dates were estimated from quadratic models fitted to each individual time series. Each daily increment in every otolith was assigned to a $2 \mathrm{~mm}$ larval length class by backcalculation, following a larval standard length - otolith growth radius relationship (see next paragraph). Therefore, a daily prey biomass estimate could be obtained for each individual increment.

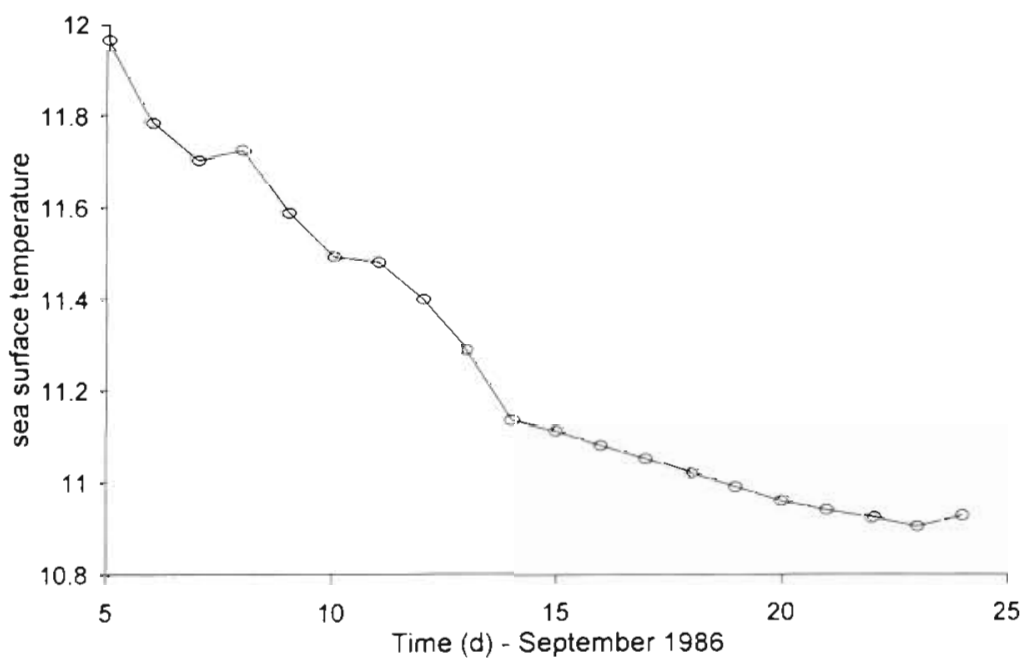

Fig. 5. Daily mean surface seawater temperature ( ${ }^{\circ} \mathrm{C}$ ). Values between 19 and 21 September interpolated from valid data (see 'Materials and methods') 


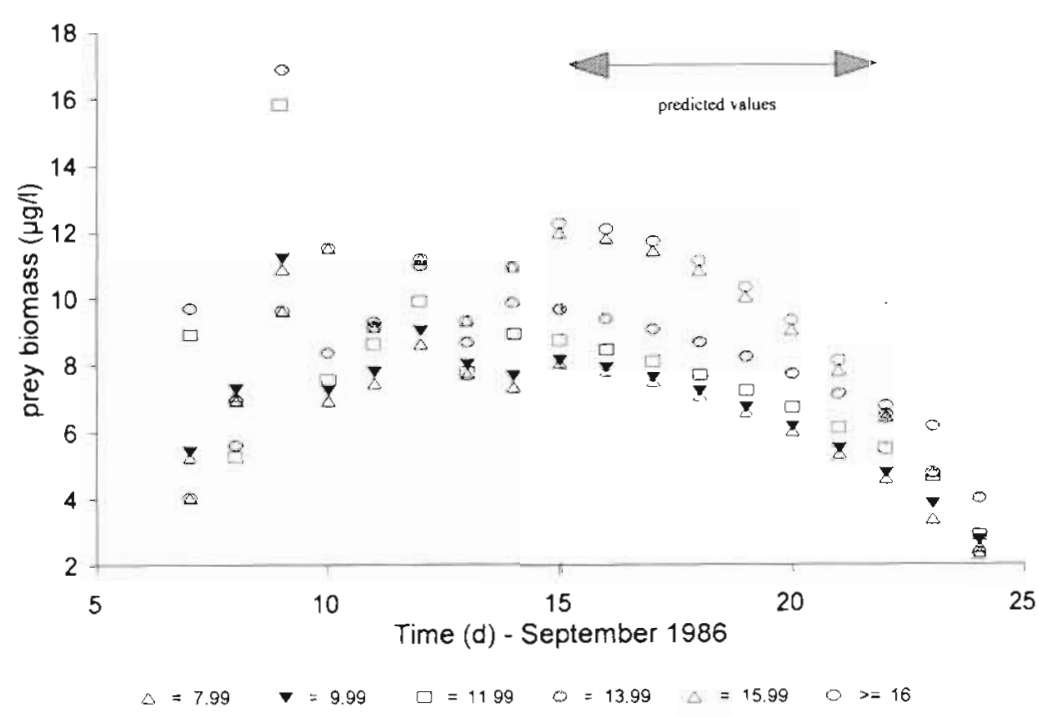

Fig. 6. Prey biomass $\left(\mathrm{g} \mathrm{l}^{-1}\right)$ available to each of the six $2 \mathrm{~mm}$ length classes. Note that 7.99 is $<8 \mathrm{~mm}, 9.99$ is $<10 \mathrm{~mm}, 11.99$ is $<12 \mathrm{~mm}, 13.99$ is $<14 \mathrm{~mm}$, 15.99 is $<16 \mathrm{~mm}$ and 16 is $\geq 16 \mathrm{~mm}$ in the figure legend. Data from 15 to 22 September were predicted from a quadratic model (see 'Results: Biological analysis')

Only increments deposited during the survey period 5 to 24 September were subsequently analysed, as no environmental data were available prior to those dates. In addition, a small number of otoliths were dissected from larvae sampled at times of the day other than midnight. Assuming that daily ring deposition is completed around midnight in herring, as in several other species (Ré 1984), it might be possible to estimate the hourly rate of otolith deposition (Tanaka et al. 1981) to account for sampling time differences. However, this technique is not valid for larvae subject to highly variable environmental conditions or performing significant vertical migrations (Sepulveda 1994), as in the present case. The width of the marginal increment relative to the width of the ring deposited on the previous day was regressed against sampling time. The relationship between \% deposition and time of sampling is non-significant (Fig. 7), so the marginal increment of otoliths sampled before midnight was not used in the analysis. At the end of the scrutiny procedure, data from 48 otoliths, of a total of 117 otoliths read, were used in the analysis (333 daily increments overall). The majority of the discarded incromonts had been deposited before the beginning of the survey.
Regression analysis of otolith increment width data

The regression model to explain variation in daily otolith increment width must include the following features.

(1) Internal factors: ontogenetic changes (underlying age- or size-dependent relationships), intra-fish variation (inherent differences between individuals), inertia in an individual fish response to environmental forcing of growth rate variations.

(2) External factors: temperature, food concentration, light, turbulence.

In general, temperature and food concentration display intrinsically low temporal variability in the sea, while light and turbulence are inherently highly variable.

A crude initial examination of daily increment growth showed a trend of increasing width from the first to the second half of the investigation for 'age' (ring number) classes, i.e. after crudely factoring out ontogenetic effects (Fig 8). Thus, the underlying external forcing of growth was generally enhancing If temperature was a major component of this external forcing, then it would be expected, within this temperature range, to also have shown an increasing trend-contrary to our observations. In addition, temperature contrast was smali $\left(<1^{\circ} \mathrm{C}\right)$, as would be expected for this parameter in a tracked water mass over approximately $20 \mathrm{~d}$. Thus, any correlation

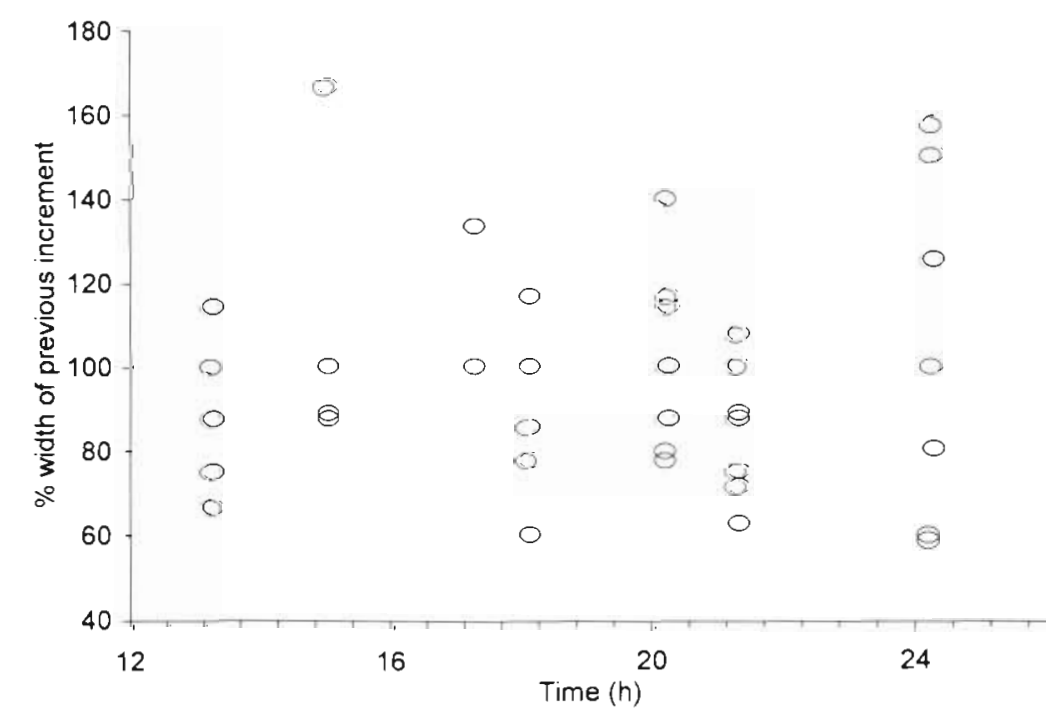

Fig. 7 Width of marginal increment, as a proportion of the previous daily increment, plotted against samplıng time of day, for otoliths not sampled at midnight 


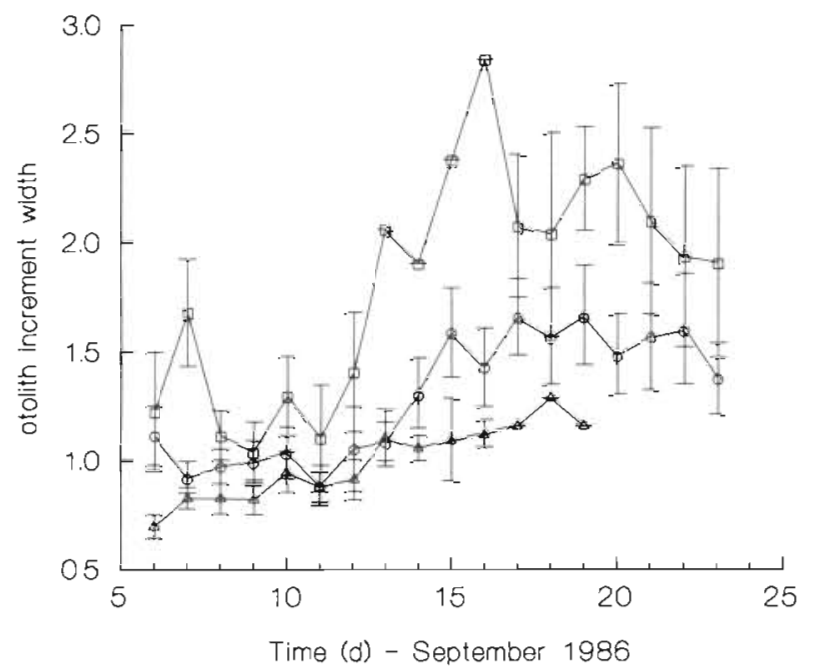

Fig. 8. Time series of mean increment widths for 3 different 'age' (ring number) classes through the survey: rings $1-9(\Delta)$, rings $10-19(0)$ and rings $\geq 20$ ( $\square$ ). Error bars are \pm 1 SE

between temperature and increment width might be statistically significant, but negative and possibly spurious. It was therefore decided to discard this factor from the regression analysis and concentrate on the more volatile parameters of light and turbulence. Prey availability also showed only small variability $( \pm 50 \%$ mean prey biomass) throughout the survey but was retained in the analysis due to its potential importance in a model of larval fish growth. An additional factor, ' $D A Y$ ', was incorporated in the model to account for additional, but unidentified, daily environmental variation to that explained by the variables measured.

Both wind and tidal processes contributed to turbulence in the water column. Nevertheless, the magnitude of the tidal component was below the critical value of $0.024 \mathrm{~W}$ $\mathrm{m}^{-2}$ characteristic of tidally mixed areas (MacKenzie \& Leggett 1991) for most of the survey, with the exception of 4 dates (16 and 19 to 21 September), when the patch was in the mixing zone between the Orkney and Shetland Isles and which coincided with periods of strong winds that may have contributed exceptionally to the displacement of the buoys. In addition, the larvae remained at shallower depths during feeding (daylight) hours (Heath et al. 1988), where wind-induced turbulence was greater and tidally induced turbulence was weaker. Consequently, it was decided to include in the model only the daily minimum (i.e. at the bottom of the mixed layer) wind-generated turbulence as an estimate of the minimum turbulence value to be experienced by an individual in the population

Since there was no a priori reason to assume that increment width should be a monotonic function of external factors, these terms were represented by polynomial functions (different order polynomials were tested). The internal factors affecting the width of an increment on an individual otolith were represented by ring number (equivalent to daily age) and the width of the 2 previous increments in the same otolith. Positive coefficients for the latter term would indicate an inertia in the physiology of otolith growth which would buffer the process against short term (day to day) variability in external factors. Thus, for an individual otolith the regression model identified was

$$
\begin{aligned}
\ln W I D T H_{t}=R I N G_{t}+\ln W I D T H_{t-1}+\ln W I D T H_{t-1}{ }^{2} \\
+\ln W I D T H_{t-2}+F O O D_{t, 1}+\text { LIGHT }_{t}+T U R B_{l} \\
+T U R B_{l}{ }^{2}+D A Y_{t}+\varepsilon_{t}=\mu_{l}+\varepsilon_{t}
\end{aligned}
$$

$W I D T H_{t}$ is the width of an individual otolith daily increment on Day $t_{i}$ WIDTH $_{l-1}$ and WIDTH $_{t-2}$ are the widths of the daily increments on Days $t-1$ and $t-2$, respectively, for the same individual otolith; $R I N G_{t}$ is the increment number within that individual otolith, deposited on Day $t_{i} L I G H T_{1}$ and $T U R B_{\ell}$ are the daily average surface light intensity and wind-induced turbulence on Day $t$, respectively; $F O O D_{l, l}$ is the average prey biomass available on Day $t$ to a larva within a particular length class $l_{i} D A Y_{l}$ is a daily environmental effect which incorporates daily variation unexplained by other environmental factors on Day $t ; \varepsilon$ is random noise $[\varepsilon \approx N(0, V)]$ and $\mu$ is the regression component of the model (Table 2).

Table 2. Multiple regression analysis of individual otolith daily increments (WIDTH, natural-log-transformed) on increment number (RING $)$, previous 2 days' increment width (WIDTH, and WIDTH $_{t-2}$, natural-log-transformed), daily average prey biomass available $\left(F O O D_{h}\right)$, daily mean light intensity at the surface (LIGHT $\left.T_{t}\right)$, wind-generated turbulence $\left(T U R B_{1}\right)$ and a term accounting for unexplained daily environmental variation $\left(D A Y_{1}\right)$. Non-significant. Estimated

\begin{tabular}{|c|c|c|c|c|c|}
\hline Variable & Coefficient & $\mathrm{SE}$ & Std coeff. & $t$-value & $p$ \\
\hline (intercept) & -0.70333 & 0.11169 & 0.0000 & -4.166 & $<0.001$ \\
\hline RING: & 0.00700 & 0.00273 & 0.1075 & 2.567 & 0.018 \\
\hline WIDTH $H_{t-1}$ & 0.41007 & 0.05426 & 0.4092 & 7.557 & $<0.001$ \\
\hline WIDTH ${ }^{2}$ & 0.16674 & 0.06185 & 0.0993 & 2.696 & 0.007 \\
\hline WIDTH $H_{t-2}$ & 0.27942 & 0.05551 & 0.2758 & 5.033 & $<0.001$ \\
\hline$L I G H T_{t}$ & 0.00273 & 0.00111 & 0.1374 & 2.459 & 0.015 \\
\hline$F O O D_{t, 1}$ & 0.00756 & 0.00639 & 0.0498 & 1.338 & $0.181^{\circ}$ \\
\hline TURB, & $2054 \times 10^{3}$ & $7.468 \times 10^{2}$ & 0.4113 & 2.751 & 0.006 \\
\hline TURB ${ }^{2}$ & $-3.726 \times 10^{6}$ & $1.665 \times 10^{6}$ & -0.3347 & -2.238 & 0.026 \\
\hline$D A Y_{t}$ & 2.24210 & 0.59270 & 0.2566 & 3.783 & $<0.001$ \\
\hline
\end{tabular}
residual variance $=0.06757$ on 292 degrees of freedom; $\mathrm{r}^{2}=0.684$; adjusted $\mathrm{r}^{2}=$ 0.674 ; number of increments $=333$; number of otoliths $=48$ 
In the model with the additional term $\alpha$, tested to investigate the effect of intra-fish variation additional to that derived from individual growth history on Days $t-1$ and $t-2, V_{\alpha}$ was not statistically significant and this term was therefore excluded. This resulted in the model given in Eq. (7). No significant autocorrelation was found among residuals from the model in individual otoliths.

\section{Regression analysis of condition factor data}

The condition factor of the larvae (CF = dry weight $\times$ standard length ${ }^{-1} \times 10^{3}$ ) differed significantly between the various length classes and sampling dates (Table 3).

A simple regression model (Table 3 ) explains $32.3 \%$ of the variance. The differences between length classes may be the result of an isometrical body development, emphasizing the need to stratify the CF according to length class when analysing the time series (see Heath 1989). Sampling date was substituted by several environmental factors (prey biomass available to each length class, light intensity at the surface and wind-induced turbulence). Note that prey availability data do not include any estimated values in this analysis. This model gave a moderately poorer fit $\left(\mathrm{r}^{2}=\right.$ 0.292 ; Table 4), although it was consistent with the model proposed for otolith microstructure.

Table 3. Effect of length class (LENGTH) and sampling date on the condition factor of the herring larvae $(n=1105)$.

$$
r^{2}=0.323
$$

\begin{tabular}{|lcccc|}
\hline Factor & df & SS & F-value & $p$ \\
\hline LENGTH & 5 & 0.177 & 34.311 & $<0.001$ \\
Sampling date & 7 & 0.272 & 37.645 & $<0.001$ \\
\hline
\end{tabular}

Table 4. Effect of length class (LENGTH; a categorical variable), prey biomass (FOOD), surface light intensity (LIGHT) and wind-generated turbulence (TURB) on the condition factor of the herring larvae $(\mathrm{n}=1105) \cdot r^{2}=0.292$

\begin{tabular}{|lrrrr|}
\hline Factor & df & SS & F-value & \multicolumn{1}{c|}{ p } \\
\hline LENGTH & 5 & 0.230 & 42.824 & $<0.001$ \\
FOOD & 1 & 0.013 & 12.245 & $<0.001$ \\
LIGHT & 1 & 0.011 & 10.627 & 0.001 \\
TURB & 1 & 0.042 & 38.853 & $<0.001$ \\
TURB & 1 & 0.165 & 152.999 & $<0.001$ \\
TURB $\times$ FOOD & 1 & 0017 & 6.291 & 0.012 \\
& 1 & & & \\
"TURB-FOOD interaction term & & & \\
\hline
\end{tabular}

\section{DISCUSSION}

Although there is little doubt about the close relationship between otolith daily increment width and somatic growth (e.g. growth in length) there has been substantial controversy regarding which of the various length back-calculation methods is most appropriate to relate otolith and body growth rates. Length back-calculation was employed here simply to assign individual daily otolith increments to $2 \mathrm{~mm}$ larval length classes, in order to produce prey biomass values for each individual increment. We decided to circumvent the potential bias introduced by back-calculation (Campana 1990, Campana \& Jones 1992) by modelling otolith growth itself, rather than somatic growth. Decoupling between otolith and somatic growth occurs at suboptimal conditions (see references in Campana \& Neilson 1985), such as extreme temperatures (Geffen 1983, Hovenkamp \& Witte 1991) or poor feeding conditions (Secor et al. 1989, Hovenkamp \& Witte 1991), but there was no evidence of either of these throughout the course of this study.

The identified model of daily growth increments in individual otoliths includes the major features of the larval growth process: ontogenetic factors such as age, and physical and biological environmental factors. The effect of recent past environment is implicitly present in the recent past growth term. Dependence on past growth history, which also incorporates inherent variation in each individual larva (environmental and otherwise, e.g. genetic), explains the vast majority $(65.7 \%)$ of the variation in the data, while the remaining variables (age and environmental conditions on the day of deposition of an individual ring) contribute $2.7 \%$ of the total variation explained by the model. The strength of the dependence on past growth history requires a considerable amount of data to investigate the individual effect of the remaining variables accurately. In general, daily growth is a complex function of ontogenetic development, individual variability, and present and past environmental factors

The width of otolith daily increments is frequently reported to be affected by the age of the fish (Campana \& Neilson 1985 and references therein). Increments are generally small at young larval stages, immediately after first feeding or first ring deposition and increase subsequently (Campana 1984). We observed a small positive effect of larval 'age' (otolith ring) on the width of daily increments (Fig. 9). The functional relationships between otolith radius and larval length at capture, and larval 'age' and length, are exponential in both cases, suggesting that somatic growth in length is siower in earlier larval stages and also that a given increase in otolith radius (daily increment width) then is associated with a relatively smaller growth in length, 


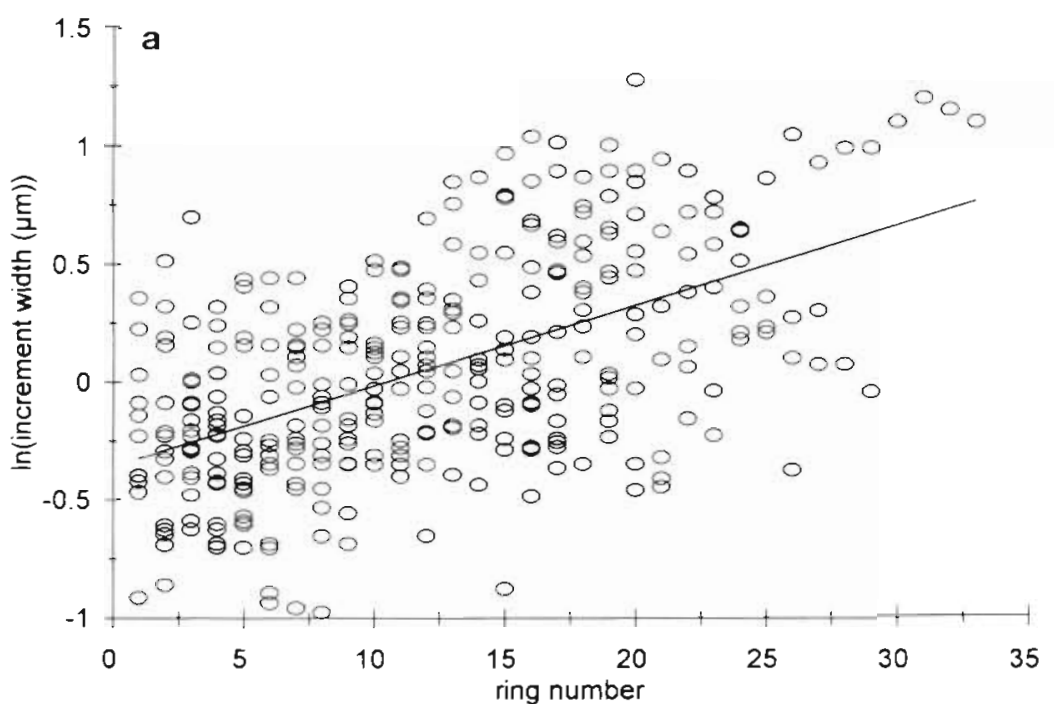

Intra-fish variation did not contribute significantly in the model because it is effectively removed by modelling present otolith increment width with an explicit (non-linear) function of its own past growth, i.e. the widths in the 2 previous days, WIDTH $H_{-1}$ and IVIDTH $_{t-2}$. Tests of several alternative models with and without autocorrelation terms demonstrated that these terms incorporated most of the variability specific to each individual larva with a particular growth history, while no autocorrelation was found in the residuals within individual otoliths. Intrafish variation in growth, specific to each larva, is likely to be the outcome of complex interactions between several factors such as genetic variability among individuals in the population, foraging experience or small-scale heterogeneity in the larval environment. The separate contribution of each of the numerous potential factors that can operate at the level of individual larvae is extremely difficult to quantify from field/experimental data, and is best explored with the assistance of mathematical modelling.

The observation that some degree of otolith growth continues even in the absence of somatic growth (e.g. during starvation; Brothers 1981) has contributed to the suggestion (Campana \& Neilson 1985) by several authors that otolith growth is conservative (Gutierrez \& Morales-Nin 1986, Hovenkamp 1989, Hovenkamp \& Witte 1991) and even represents a running average of somatic growth (Bradford \& Geen 1987). However, growth in length could be a conservative process as well, as fish may alter the relative ratio of structural: reserve material to compensate for short-term changes in the environment. The relative amount of reserves is lower in fish larvae than in juveniles or adults and therefore growth rates in length are likely to mirror changes in the growth environment more closely during the larval stage. Nevertheless, even during the larval stage, daily somatic growth can hardly be expected to be totally independent of previous growth. Although we are not aware of any investigation of the relative importance of the influence of previous growth on otolith versus somatic growth, the detection of a conservative component in otolith growth should not invalidate its usefulness in the study of daily growth variation, as long as its effect is incorporated into the model.

Surface light intensity had a positive effect on otolith growth. Light intensity varied considerably throughout the survey and also exhibited a significant positive effect on larval condition factor, which was calculated from independent samples. Many fish the width of any ring was significantly autocorrelated 
larvae, including herring (Blaxter \& Batty 1990), cannot feed in the dark and consequently feeding is limited by light intensity, as demonstrated in several laboratory (Hunter 1968) and field (Gilbert et al. 1992) studies. Light intensity may have a positive effect on growth through a variety of mechanisms. Higher light intensity increases larval activity and swimming speed (Batty 1987), which could result in the search of greater volumes and increased contact rate with prey, Food selection is influenced by light intensity (Fossum 1983), e.g by enhancing detectability of less conspicuous prey. Light intensity also affects vertical distribution of herring larvae (Heath et al. 1988 , Munk et al. 1989) as well as other fish (Perry \& Neilson 1988, Olla \& Davis 1990), enabling the larvae to feed over a greater range of depths where prey may be concentrated.

We decided to disregard surface water temperature a priori from our analysis, although temperature is generally regarded as one of the most important factors influencing both otolith (Gutierrez \& Morales-Nin 1986, Campana \& Hurley 1989) and somatic growth. Nevertheless, we considered that the small decline in surface water temperature $\left(0.83^{\circ} \mathrm{C}\right)$ over the survey period was well within the range of temperature variation the larvae would be exposed to by their vertical migration even within the mixed layer. In addition, no significant effect of temperature on otolith growth was found in several studies where the range of temperatures was small (Ré 1983, Suthers et al. 1989).

The effect of turbulence on plankton contact rates has been extensively addressed in the literature since Rothschild \& Osborn (1988) extended Gerritsen \& Strickler's (1977) work on the importance of the relative speeds of predators and prey on contact rate between planktonic organisms. Turbulence is also known to influence vertical migration patterns of fish larvae (Heath et al. 1988, Munk et al. 1989). The relationship between turbulence and growth is a complex one. Fish larvae are known to benefit from prey patchiness (Cushing 1983) and larval growth in species like northern anchovy Engraulis mordax is heavily dependent on the stability of food patches, which are dispersed by turbulence (Bloomer et al. 1994). Increasing turbulent velocity results in an increase in encounter rate between planktonic particles (Rothschild \& Osborn 1988), counterbalancing the effect of patch dispersion on growth (Davis et al. 1991). This positive effect of turbulence on growth has been observed in several fish larvae species (Mackenzie et al. 1990, Sundby \& Fossum 1990) including herring (Muelbert et al. 1994). However, turbulence above a certain level

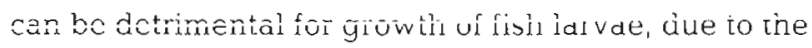
progressive reduction in the time available for pursuit after each encounter with prey and consequent de- crease in capture success (Mackenzie et al. 1994). In summary, as turbulence increases the patches of prey disperse, with negative consequences for the growth of the larvae. Increasing turbulence, however, boosts encounter rate between larvae and their prey, thus effectively increasing apparent prey concentration. At turbulence beyond an optimum level, time available for prey capture is progressively reduced, with adverse effects on larval growth. Although fish larvae have been shown to be able to optimise their feeding behaviour in a patchy environment (herring: Gallego 1994; cod: Munk 1995) and to modify their foraging strategy in response to the level of turbulence (MacKenzie \& Kirrboe 1993), our results from otolith microstructure and condition factor analyses showed that windinduced turbulence had a significant dome-shaped effect on the growth of the larvae. The hypothesized initial detrimental effect of lower levels of turbulence could not be observed in our data, possibly because windy weather prevailed through most of the survey. The wind speed that would generate optimal turbulence for the growth of herring larvae, as estimated from our otolith growth model, was $14.5 \mathrm{~m} \mathrm{~s}^{-1}(90 \%$ confidence interval: 13.5 to $17.7 \mathrm{~m} \mathrm{~s}^{-1}$ ), which is extremely close to the optimum wind speed of $15.3 \mathrm{~m} \mathrm{~s}^{-1}$ derived from Mackenzie et al.'s (1994) model for cod larvae and agrees with Sundby et al.'s (1994) predictions of an optimum at wind speeds $>10 \mathrm{~m} \mathrm{~s}^{-1}$. The effect of tidally induced turbulence is greatest near the sea bed, while the larvae remained nearer to the surface during the feeding (daylight) hours. Nevertheless, some contribution of tidal turbulence cannot be ruled out, particularly when the patch crossed the shallower Fair Isle Channel. Unfortunately, strong winds coincided with the passage of the patch through this area and we are not totally confident about the accuracy of the current speed data derived from buoy displacement at that time.

We retained prey concentration in the final regression model of otolith increment width, although it was statistically non-significant, due to the potential biological importance of food availability on growth. Prey biomass declined towards the end of the survey, as the patch travelled from the more productive Fair Isle Channel into the North Sea. Prey biomass available to the various length classes, which varied between $>2.6$ and $<16.8 \mathrm{\mu g} \mathrm{l}^{-1}$, was in the lower end of the range of prey densities reported in the literature reviewed by MacKenzie et al. (1990) However, from a total of all potential prey, prey biomass reported here included exclusively species/stages found in the stomachs of the larvae. Besides, these values were weighed by the relative proportion of the larval population present within the depth layer sampled. Taking these 2 aspects into consideration, observed prey biomass may be closer to 
the median food density given by MacKenzie et al. (1990), which was $31 \mu \mathrm{g} \mathrm{l}^{-1}$. Although we believe that by delimiting prey biomass as described above we portrayed more adequately the food environment of the herring, the fragmentary nature of the zooplankton time series meant that a significant proportion of these data was predicted from a quadratic model, adding a further potential source of error. Nevertheless, in a tracked water body, depth integrated zooplankton concentration should vary only slowly in relation to meterological forcing factors such as light and turbulence over the time scales considered here $(<20 \mathrm{~d})$ and, indeed, the variability in the 'real' data was relatively small. Although the use of interpolated data is an unfortunate consequence of the research vessel's additional sampling commitments rather than a scientific justification, we are confident about the validity of the other arguments discussed above and believe that prey availability contributed relatively little towards remaining overall variability explained by environmental factors such as light and turbulence. However, these arguments should not be interpreted as a lack of a general relationship between prey availability and larval growth. On the contrary, food available to each length class was a significant factor in our less detailed supporting model of condition factor. Stomach fullness is not likely to have exerted a major influence on the significance of this factor, because these larvae were sampled around $( \pm 1 \mathrm{~h})$ midnight. The presence of a significant interaction between food and turbulence in this model could be expected, as encounter rates increase relatively faster with turbulence at lower prey densities (MacKenzie \& Leggett 1991). Although this and other interaction terms investigated (see 'Results') were not statistically significant in the final regression model of otolith increment width, the strength of dayto-day growth dependence, which cannot be tested by condition factor analysis, may have obscured these subtler effects. A similar argument may be made about the lack of statistical significance of prey availability in the otolith model, especially considering that some of these data were interpolated in that model.

We know that herring larvae in this patch adjusted their vertical migration patterns in response to several physical paramenters (Heath et al. 1988). Together with the present analysis of larval growth, this investigation supports the hypothesis (MacKenzie \& Leggett 1991) that fish larvae may be able to respond to combined stimuli such as prey abundance, light intensity and turbulence to optimise foraging success.

Acknowledgements. The analysis of these data was partially funded by the EU MAST 2 program grant no. MAS2-CT920032-C. We gratefully acknor:ledge the useful comments of 3 anonymous referees.

\section{LITERA.TURE CITED}

Batty RS (1987) Effect of light intensity on activity and foodsearching of larval herring. Clupea harengus: a laboratory study, Mar B1ol 94:323-327

Blaxter JHS, Batty RS (1990) Herring behaviour in the light and dark. In: Herring PJ, Campbell AK, Whitfield M, Maddock L (eds) Light and life in the sea. Cambridge University Press, Cambridge, p 1031-1049

Bloomer SF, Cochrane KL, Field JG (1994) Towards predicting recruitment success of anchovy Engraulis capensis Gilchrist in the southern Benguela system using environmental variates: a rule-based model. S Afr J Mar Sci 14 $107-119$

Bowers DG. Simpson JH (1987) Mean position of tidal fronts in European-shelf seas. Cont Shelf Res 7(1):35-44

Bradford MJ, Geen GH (1987) Size and growth of juvenile chinook salmon back-calculated from otolith growth increments. In: Summerfelt RC, Hall GE (eds) The age and growth of fish. Iowa State University Press, Ames, p $453-461$

Brothers EB (1981) What can otolith microstructure tell us about daily and subdaily events in the early life history of fish? Rapp P-V Réun Cons int Explor Mer 178:393 394

Campana SE (1984) Microstructural growth patterns in the otoliths of larval and juvenile starry flounder, Platichthys stellatus. Can J Zool 62:1507-1512

Campana SE (1990) How reliable are growth back-calculations based on otoliths? Can J Fish Aquat Sci 47 : $2219-2227$

Campana SE, Hurley PCF (1989) An age- and temperaturemediated growth model for cod (Gadus morhua) and haddock (Melanogrammus aeglefinus) larvae in the Gulf of Maine. Can J Fish Aquat Sci 46(4):603-61.3

Campana SE, Jones CM (1992) Analysis of otolith microstruc. ture data. Can Spec Publ Fish Aquat Sci 1.17:73-100

Campana SE, Moksness E (1991) Accuracy and precision of age and hatch date estimates from otolith microstructure examination. ICES J Mar Sci 48:303-316

Campana SE, Neilson JD (1985) Microstructure of fish otoliths. Can J Fish Aquat Sci 42(5):1014-1032

Cushing DH (1983) Are fish larvae too dilute to affect the density of their food organisms? J Plankton Res 5(6):847-854

Davis CS, Flierl GR, Wiebe PH, Franks PJS (1991) Micropatchiness, turbulence and recruitment in plankton. J Mar Res 49(1): 109-151

Dunn J, Mitchell RB, Ritchie BJ (1985) A new multidepth high speed plankton sampler. Comm Meet Int Coun Explor Sea CM-ICES/L:7

Fossum P (1983) Digestion rate of food particles in the gut of Larval herring (Clupea harengus L.). FiskerDir Skr Ser Havunders 17:347-3.57

Fuiman LA (1994) The interplay of ontogeny and scaling in the interactions of fish larvae and their predators. J Fish Biol 45(Suppl A):55-79

Gallego A (1994) Changes in the swimming behaviour of larval herring in response to two different prey densities. J Mar Biol Ass UK 74(4):555-558

Geffen AJ (1983) The deposition of otolith rings in Atlantic salmon, Salmo salar L., embryos. J Fish Biol 23:467-474

Gerritsen J, Strickler JR (1977) Encounter probabilities and community structure in zooplankton: a mathematical model. J Fish Res Bd Can 34:73-82

Gilbert M, Fortier L, Ponton D, Drolet R (1992) Feeding ecology of manne fish larvae across the Great Whale River plume in seasonally ice-covered southeastern Hudson Bay. Mar Ecol Prog Ser 84:19-30 
Gjosceter $\mathrm{H}_{1}$ Oiestad V (1981) Growth patterns in otoliths as an indication of daily growth variations of larval herring (Clupea harengus) from an experimental ecosystem. Comm Meet Int Coun Explor Sea CM-ICES/H:31

Gutiérrez E, Morales-Nin B (1986) Time series analysis of daily growth in Dicentrarchus labrax L. otoliths. J Exp Mar Biol Ecol 103:163-179

Hay SJ, Kiorboe T, Matthews A (1991) Zooplankton biomass and production in the North Sea during the Autumn Circulation Experiment, October 1987-March 1988. Cont Shelf Res 11 (12):1453-1476

Heath MR (1989) A modelling and field study of grazing by hermng larvae. Comm Meet Int Coun Explor Sea, Early Life History Symposium, 4

Heath MR (1992) Field investigations of the early life: stages of marine fish. Adv Mar Biol 28:1-174

Heath MR, Henderson EW, Baird DL (1988) Vertical distribution of herring larvae in relation to physical mixing and illumination. Mar Ecol Prog Ser 47:211-228

Heath MR, MacLachlan P, Martin JHA (1987) Inshore circulation and transport of herring larvae off the north coast of Scotland. Mar Ecol Prog Ser 40:11-23

Heath MR, Rankine PW (1988) Growth and advection of larval herring (Clupea harengus L.) in the vicinity of the Orkney Isles. Estuar Coast Shelf Sci 27(5):547-565

Houde ED (1987) Fish early life dynamics and recruitment variability. Am Fish Soc Symp 2:17-29

Houde ED (1994) Differences between marine and freshwater fish larvae: implications for recruitment. J Mar Sci 51(1): 91-97

Houde ED, Schekter RC (1980) Feeding by marine fish larvae: developmental and functional responses. Environ Biol Fish 5:315-334

Hovenkamp F (1989) Within-season variation in growth of larval plaice (Pleuronectes platessa L.). Rapp P-V Réun Cons Int Explor Mer 191:248-257

Hovenkamp F, Witte JIJ (1991) Growth, otolith growth and RNA/DNA ratios of larval plaice Pleuronectes platessa in the North Sea 1987 to 1989. Mar Ecol Prog Ser 70:105-116

Hunter JR (1968) Effects of light on schooling and feeding of jack mackerel, Trachurus symmetricus. J Fish Res Bd Can 25(2):393-407

Lough RG, Pennington M, Bolz GR, Rosenberg AA (1982) Age and growth of larval Atlantic herring. Clupea harengus $\mathrm{L}$., in the Gulf of Maine-Georges Bank region based on otolith growth increments. Fish Bull US 80(2):187-199

MacKenzie BR, Kiørboe T (1993) Feeding and swimming behaviour of larval cod and herring in calm and turbulent environments. Comm Meet Int Coun Explor Sea, Symposium on Cod and Climate Change 24

Mackenzie BR, Leggett WC (1991) Quantifying the contribution of small-scale turbulence to the encounter rates between larval fish and their zooplankton prey: effects of wind and tide. Mar Ecol Prog Ser 73:149-160

MacKenzie BR, Leggett WC, Peters RH (1990) Estimating larval fish ingestion rates: can laboratory derived values be reliably extrapolated to the wild? Mar Ecol Prog Ser 67: $209-225$

MacKenzie BR, Miller TJ, Cyr S, Leggett WC (1994) Evidence for a dome-shaped relationship between turbulence and larval fish ingestion rates. Limnol Oceanogr 39(8): 1790-1799

Messieh SN, Moore DS, Rubec P (1987) Estimation of age and growth of larval Atlantic herring as inferred from examination of daily growth increments of otoliths. In: Summerfelt $\mathrm{RC}$. Hall GE (eds) The age and growth of fish. Iowa State University Press, Ames, p 433-442
Moksness E, Wespestad V (1989) Ageing and back-calculating growth rates of Pacific herring, Clupea pallasid, larvae by reading daily growth otolith increments. Fish Bull US 87:509-513

Muelbert JH, Lewis MR, Kelley DE (1994) The importance? of small-scale turbulence in the feeding of herring larvae. J Plankton Res 16(8):927-944

Munk P (1995) Foraging behaviour of larval cod (Gadus morhua) influenced by prey density and hunger. Mar Biol 122:205-212

Munk P, Kiørboe T, Christensen V (1989) Vertical migration of herring, Clupea harengus, larvae in relation to light and prey distribution. Environ Biol Fish 26(2):87-96

Olla BL, Davis MW (1990) Behavioural responses of juvenile walleye pollock Theragra chalcogramma Pallas to light, thermoclines and food: possible role in vertıcal distribution. J Exp Mar Biol Ecol 135:59-68

Pepin P (1988/1989) Predation and starvation of larval fish: a numerical experiment of size- and growth-dependent survival. Biol Oceanogr 6:23-44

Pepin P (1989) Using growth histories to estimate larval fish mortality rates. Rapp P-V Réun Cons Int Explor Mer 191: $324-329$

Perry RI, Neilson JD (1988) Vertical distributions and trophic interactions of age-0 Atlantic cod and haddock in mixed and stratified waters of Georges Bank. Mar Ecol Prog Ser 49:199-214

Rankine PW, Cargill LH (1991) The automated measurement of growth increments of larval fish otoliths using image analysis enhancement procedures. Scottish Fisheries Working Paper 25/91

Ré $P$ (1983) Growth of pilchard larvae Sardina pilchardus (Walbaum, 1972) in relation to some environmental factors. Invest Pesq 47(2):277-283

Ré P (1984) Evidence of daily and hourly growth in pilchard larvae based on otolith growth increments, Sardina pilchardus (Walbaum, 1792). Cybium 8(1):33-38

Rice JA, Miller TJ, Rose KA, Crowder LB, Marschall EA, Trebitz AS, DeAngelis DL (1993) Growth rate variation and larval survival: inferences from an individual-based size-dependent predation model. Can J Fish Aquat Sci 50: $133-142$

Rothschild BJ, Osborn TR (1988) Small-scale turbulence and plankton contact rates. J Plankton Res 10(3):465 474

Secor DH, Dean JM, Baldevarona RB (1989) Comparison of otolith growth and somatic growth in larval and juvenile fishes based on otolith length/fish length relationships. Rapp P-V Réun Cons Int Explor Mer 191:431-4.38

Sepúlveda A (1994) Daily growth increments in the otoliths of European smelt Osmerus eperlanus larvae. Mar Ecol Prog Ser 108:33-42

Sundby S, Ellersten B, Fossum P (1994) Encounter rates between first-feeding cod larvae and their prey during moderate to strong turbulent mixing. ICES Mar Sci Symp 198:393-405

Sundby S, Fossum P (1990) Feeding conditions of Arcto-Norwegian cod larvae compared with the Rothschild-Osborn theory on small-scale turbulence and plankton contact rates. J Plankton Res 12(6):1153-1162

Suthers IM, Frank KT, Campana SE (1989) Spatial comparison of recent growth in postlarval Atlantic cod (Gadus morhua) off southwestern Nova Scotia: infenor growth in a presumed nursery area. Can J Fish Aquat Sci 46(Suppl 1): $113-121$

Tanaka K, Mugiya Y, Yamada J (1981) Effects of photoperiod and feeding on daily growth patterns in otolith of juvenile Tilapia nilotica. Fish Bul] US 79(3):459-466

Manuscript first received: October 12, 1995

Revised version accepted: December 28, 1995 